\title{
EDITORIAL
}

\section{Energía solar: nuevos desafíos para el desarrollo y crecimiento sostenible de la agricultura en zonas desérticas}

\author{
Solar energy: new challenges for development and sustainable growth of agriculture in \\ desert zones.
}
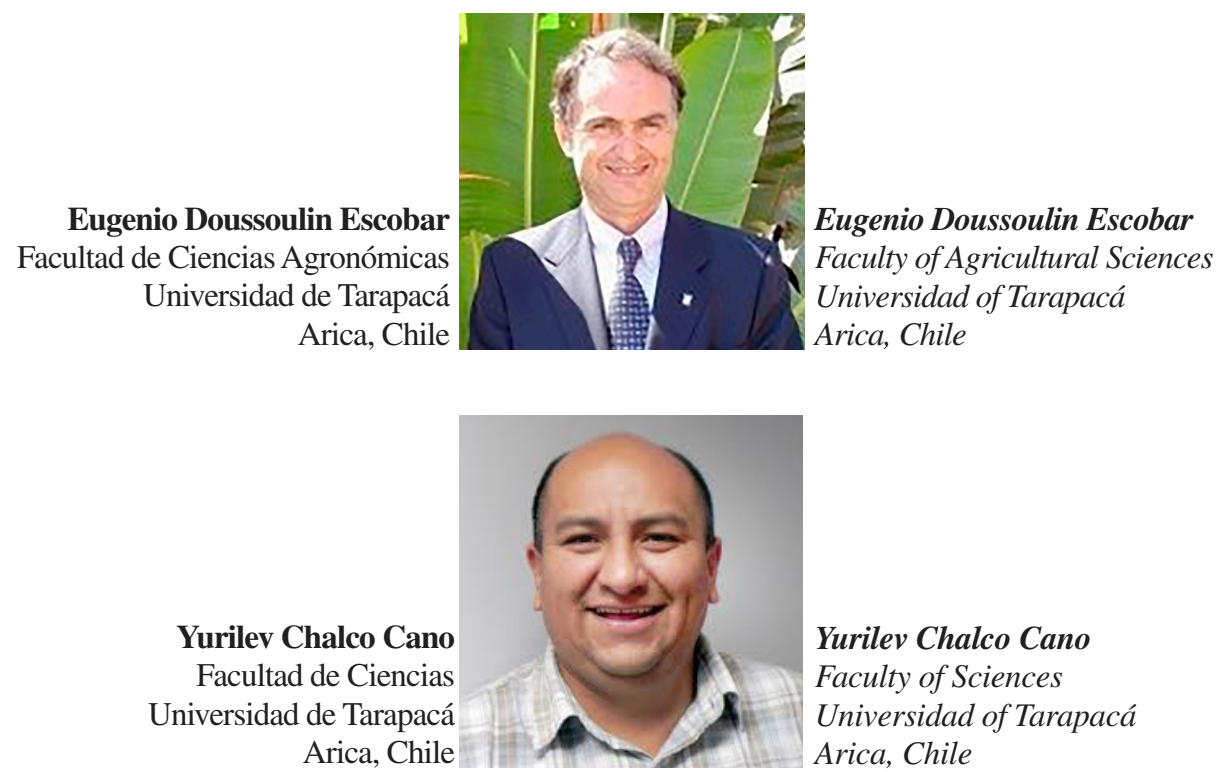

Desde los albores de la historia, el sol ha acompañado con su luz y calor la actividad del hombre. De hecho, en las culturas primitivas lo consideraban como un elemento único pues, al contrario de las estrellas, que aparecían fijas en el firmamento, cada día trazaba el curso desde el amanecer hasta el ocaso, como única fuente de luz y calor. Por ello le atribuyeron propiedades excepcionales y construyeron observatorios y lugares de culto como los megalíticos de Stonehenge en Inglaterra (2200-1600 a.C.) y Carnac (6000-2000 a.C.) en Francia. Aún más, el sol ha sido considerado por diversas culturas como una deidad, como es el caso de Amon-Ra, dios del sol y de la vida en el antiguo Egipto; Helios en la mitología griega; Tonatiuh o Tonatiuhtéotl para los aztecas; Inti para los inkas del Tawantinsuyu y Willkakuti para los aymaras, que esperaban cada 21 de junio "el retorno del Sol", para así comenzar un nuevo tiempo en la vida de las mujeres y hombres del altiplano andino.
The sun has accompanied human activity with its light and heat since the dawn of history; primitive cultures considered it as a unique element, since in contrast to the stars, which appear to be fixed in the sky, the sun traces a course in the sky from dawn to dusk as the only source of light and heat. Because of this exceptional properties were attributed to it, and observatories and places of worship were built such as Stonehenge in England (2200-1600 B.C.) and Carnac (6000-2000 B.C.) in France. The sun was considered as a deity by a number of cultures, such as Amon-Ra, god of the sun and life in ancient Egypt, Helios in Greek mythology, Tonatiuh or Tonatiuhtéotl for the Aztecs, Inti for the Incas (tawantinsuyu) and Willkakuti for the Aymaras; these last waited every June 21 for the "return of the sun", that signified the beginning of a new time in the life of the women and men of the Altiplano.

The sun formed about 4.6 billion years ago; the first primates appeared on the Earth about 70 
El Sol se formó hace aproximadamente 4.600 millones de años y la aparición de los primeros primates sobre la Tierra, que fueron la base evolutiva de la especie humana actual, ocurrió hace unos 70 millones de años. En el periodo neolítico, la economía de las sociedades humanas evolucionó desde la pesca, caza y recolección de frutos hacia el desarrollo progresivo del cultivo de la tierra, cuyo inicio se sitúa 10.000 a.C. Este proceso se atribuye a crecientes necesidades de alimentación para una población ya en aumento, la cual se basó inicialmente en diversas gramíneas como el farro, el trigo escanda y la cebada, y luego los guisantes, lentejas, garbanzos y lino. Ya en aquella época y tal vez en forma intuitiva, el ser humano consideraba la influencia del sol, la luna y otros astros sobre las distintas tareas agrícolas.

En la Antigua Grecia, Aristóteles propuso una hipótesis que sugería que la luz solar estaba directamente relacionada con el desarrollo del color verde de las hojas de las plantas, idea que inicialmente no fue considerada. Diversos científicos avanzaron progresivamente a través de los siglos en distintos frentes del conocimiento, respecto a la fotosíntesis, y en el año 1942 el químico Melvin Calvin detectó la secuencia de reacciones químicas generadas por las plantas al transformar dióxido de carbono gaseoso y agua en oxígeno e hidratos de carbono, lo que en la actualidad se conoce como ciclo de Calvin. Ello le valió el Premio Nobel de Química 1961. Este descubrimiento, junto con otros notables avances en la ciencia, ha permitido concluir que la luz solar, además de cumplir un rol crucial en la fotosíntesis, es determinante en otros procesos claves para el desarrollo y crecimiento vegetal, tales como la fotomorfogénesis y el fotoperiodo.

Si nos situamos en el norte de Chile, resulta altamente interesante observar que la radiación solar incidente, del orden de $7,15 \mathrm{Kwh} / \mathrm{m} 2$ en superficies horizontales, derivados de la transparencia de la atmósfera y del importante número de días con escasa o ninguna nubosidad, solo es superada a nivel global por la región de Marigat, Kenia. Ello provee excepcionales condiciones para la producción de energía a partir de la radiación solar y constituye un permanente desafío para la innovación tecnológica en agricultura. Lo anterior dice relación con el elevado potencial fotosintético derivado de esta condición, expresado en la alta capacidad de producción de biomasa vegetal, con valores del orden de $2 \mathrm{~kg}$ de materia seca por $\mathrm{m} 2 /$ año, lo que duplica los valores determinados en la zona sur del país. million years ago, the evolutionary base of the current human species. The economy of human societies evolved in the Neolithic period from fishing, hunting and gathering to a progressive development of cultivation of plants, beginning about 12000 years ago. This process is attributed to the growing food needs of an already increasing population; it was initially based on Graminae such as spelt wheat and barley, and later green peas, lentils, chickpeas and flax. Already in this time and perhaps intuitively, humans considered the influence of the sun, moon and other astral bodies on different agricultural tasks.

In ancient Greece, Aristotle proposed the hypothesis that sunlight was directly related to the development of the green color of plant leaves, which was not accepted originally. A number of other scientists advanced progressively over the centuries in knowledge about photosynthesis, and in 1942 the chemist Melvin Calvin deduced the sequence of chemical reactions of plants which transform carbon dioxide into oxygen and carbohydrates, now called the Calvin cycle, which earned him the Nobel Prize in chemistry in 1961. This discovery and other notable advances in science have shown that sunlight, as well as playing a crucial role in photosynthesis, is also determinant in other key processes of plant growth and development such as photomorphogenesis and the photoperiod.

The incident solar radiation in northern Chile is about $7.15 \mathrm{Kwh} / \mathrm{m}^{2}$ on horizontal surfaces, due to the transparency of the atmosphere and the number of days with no or almost no clouds; higher values have only been recorded in the region of Marigat, in Kenya. This provides exceptional conditions for energy production from solar radiation, and is a permanent challenge for technological innovation in agriculture. This is due to the high photosynthetic potential derived from the high solar radiation; it is expressed in the high capacity of plant biomass production, with values around $2 \mathrm{~kg} \mathrm{~m}^{-2}$ year-1 of dry mass, which is double that of values found in the south of the country. Even though there have been important advances in the development of agriculture in the north of the country, the high solar irradiation in large extensions of land is still only partially used. Doing so will require the application of advanced technology in all productive factors, especially those associated with the arid desert ecosystem such as the intelligent use 
Por ello, aun cuando se ha avanzado en forma importante en el desarrollo de la agricultura en el norte del país, todavía existe un potencial solo parcialmente utilizado, en lo pertinente al cabal aprovechamiento de las altas condiciones de irradiación solar en vastas extensiones. Ello ineludiblemente debe asociarse con aplicaciones tecnológicas avanzadas en cada uno de los factores productivos, particularmente aquellos asociados al ecosistema árido desértico imperante, como el uso inteligente del agua y el manejo del estrés iónico, para el logro de resultados notables en términos de producción y productividad agrícola, en forma sostenible y rentable. A nivel internacional, la producción de cultivos en invernaderos, en zonas áridas, sin duda ya no es noticia. Sin embargo, es importante destacar la avanzada tecnología que ya se está aplicando en la región árida australiana de Port Augusta, con la puesta en marcha de prototipos de invernaderos en el desierto, que con el aporte de la luz del sol y el agua obtenida a partir de la desalinización de agua de mar, están permitiendo el cultivo de tomates con manejo orgánico, en sustratos con fibra de coco, ya en forma comercial. Lo brevemente indicado permite visualizar los notables desafíos, oportunidades y proyección futura para nuestra región en este ámbito, más aún en el escenario de incerteza global determinada por el cambio climático, focalizando estrategias corporativas plasmadas en crecientes emprendimientos e inversiones de desarrollo agrícola en áreas desérticas, iniciativas insospechadas en décadas pasadas. of water and management of ionic stress, among others, to achieve sustainable and profitable results in agricultural production and productivity. International crop production in greenhouses in arid zones is not new, however it is worth indicating the advanced technology which is being applied in the arid Australian region of Port Augusta with prototypes of desert greenhouses; the sunlight and water obtained from desalinization of seawater are already commercially producing tomatoes with organic management in cocoanut fiber substrate.

Thus we can visualize notable challenges, opportunities and future projections for our region in this ambit in the global scenario of uncertainty produced by climate change, which is focusing corporate strategies in growing ventures and investment in agriculture development in desert areas, which were not even dreamed of in past decades. 